\title{
Effects of Acceptor Structure on Charge-Transfer Complexation in Aqueous Polyelectrolyte Solution
}

\author{
Yoshiya Kawabata, ${ }^{*}$ Tomoyuki Itaya, ${ }^{* *}$ Yuki Sasaki, Hiroshi OchiaI, ${ }^{* * *}$ \\ Kazuyoshi Ueda, and Akira Imamura ${ }^{\dagger}$
}

\author{
Department of Chemistry, Faculty of Science, Hiroshima University, \\ Kagamiyama, Higashi-Hiroshima 739, Japan \\ * Department of Nuclear Engineering, Faculty of Engineering, Kyushu University, Fukuoka 812, Japan \\ ** Department of Applied Chemistry, Faculty of Engineering, Ehime University, Matsuyama 790, Japan \\ *** Present Address: Department of Science Education, Faculty of Education, Hiroshima University, \\ Higashi-Hiroshima 739, Japan
}

(Received June 24, 1996)

\begin{abstract}
Charge-transfer (CT) complexation between 1-pyrenesulfonate ( $\mathrm{PyS}^{-}$) (donor) and 9,10-anthraquinone-1sulfonate (1-AQS ${ }^{-}$) (acceptor), and between $\mathrm{PyS}^{-}$and 9,10-anthraquinone-2-sulfonate (2-AQS ${ }^{-}$) (acceptor) in the solution of poly(1,1-dimethyl-3,5-dimethylenepiperidinium chloride) $\left(\mathrm{PDDP}^{+} \mathrm{Cl}^{-}\right)$was investigated by absorption spectroscopy, viscosity and solubility measurements, and molecular orbital calculation. New broad UV bands corresponding to CT complexation between $\mathrm{PyS}^{-}$and 1- or 2-AQS ${ }^{-}$were observed only when the polycation was present in the system. A continuous variation method for both systems showed the stoichiometries of the CT complexes were both $1: 1$ in donor:acceptor composition. Reduced viscosity measurements showed to $\eta_{\mathrm{sp}} / c$ of $\mathrm{PDDP}^{+} \mathrm{Cl}^{-}$in $\mathrm{Na}^{+} \mathrm{PyS}^{-} / \mathrm{Na}^{+} 2-\mathrm{AQS}^{-}$solutions decrease more rapidly than in $\mathrm{Na}^{+} \mathrm{PyS}^{-} / \mathrm{Na}^{+} 1-\mathrm{AQS}^{-}$solutions as the salt concentration increase. Solubility measurements suggested that the polymer precipitated more easily in $\mathrm{Na}^{+} \mathrm{PyS}^{-} / \mathrm{Na}^{+} 2-\mathrm{AQS}^{-}$than in $\mathrm{Na}^{+} \mathrm{PyS}^{-} / \mathrm{Na}^{+} 1-\mathrm{AQS}^{-}$solution. These results suggest that interactions between the polycation and the CT complex for $\mathrm{Na}^{+} \mathrm{PyS}^{-} / \mathrm{Na}^{+} 2-\mathrm{AQS}^{-}$are stronger than that for $\mathrm{Na}^{+} \mathrm{PyS}^{-} / \mathrm{Na}^{+} 1-\mathrm{AQS}^{-}$. Plausible structures of the CT complexes are discussed on the basis of the HOMO and LUMO energies and molecular orbital symmetry obtained by the MOPAC semi-empirical molecular orbital calculation program. KEY WORDS Polyelectrolyte/Counterion Binding/ Charge-Transfer / Anthraquinonesulfonate /
\end{abstract}

Polyelectrolytes have many ionizable groups on their side chains or polymer backbone. In aqueous solution, they dissociate into polyions and counter ions. Charged groups on the polyion form a strong electrostatic field and attract a number of oppositely charged ions by an electrostatic force. This electrostatic interaction is known as counter ion binding, and this is one of the characteristic properties of a polyelectrolyte solution. ${ }^{1}$ Extensive studies have been reported on systems between a variety of counter ions and various polyions. ${ }^{2-13}$ As a result of the counter ion binding, counter ions are concentrated around a polyion. This may induce interactions among counter ions in the vicinity of a polyion.

When counter ions that have both hydrophilic and hydrophobic groups are added to aqueous polyelectrolyte solution, the counterions may associate with each other through hydrophobic or van der Waals interactions. By using simple aromatic counterions, i.e., ethylbenzenesufonate ion or naphthalenesulfonate ion, we investigated association behavior through stacking and hydrophobic interactions in aqueous poly(allylammonium chloride) $\left(\mathrm{PAAH}^{+} \mathrm{Cl}^{-}\right.$) solution. ${ }^{14-16}$ If electron-donative (donor) and electron-acceptive (acceptor) molecules are used as hydrophobic counterions, they may induce a charge-transfer (CT) interaction. This may give important information about intermolecular interactions for a model system of enzyme-coenzyme complex or energy transfer in biological systems. However, reports on CT interactions in aqueous media are relatively rare, ${ }^{17}$ due to low solubility of aromatic compounds in an aqueous solution. We studied such a system in aqueous

\footnotetext{
† To whom correspondence should be addressed.
}

polymer solutions by using 9,10-dimethoxyanthracene2-sulfonate, 1-pyrenesulfonate $\left(\mathrm{PyS}^{-}\right)$or anthracene-2sulfonate as donor hydrophobic counterions and 9,10anthraquinone-2-sulfonate (2-AQS ${ }^{-}$) as an acceptor counterion and observed $\mathrm{CT}$ interactions between them. ${ }^{18-20}$ In these studies, the effects of the difference of the polymer structure were investigated using PAAH ${ }^{+} \mathrm{Cl}^{-}$, poly(1,1-dimethyl-3,5-dimethylenepiperidinium chloride) $\left(\mathrm{PDDP}^{+} \mathrm{Cl}^{-}\right)$and poly(vinylammonium chloride) $\left(\mathrm{PVAH}^{+} \mathrm{Cl}^{-}\right)$, and showed that CT complexation occurs effectively in the polymer systems that have high charge density on the polymer chain, small volume of dissociative side chain and high flexibility of main chain.

In the present work, we investigated the effects of the difference in the chemical structures of acceptor molecules on CT complexation. Interaction was investigated by absorption spectroscopy, viscosity and solubility measurements, and molecular orbital calculation. 9,10anthraquinone-1-sulfonate (1-AQS ${ }^{-}$) and 9,10-anthraquinone-2-sulfonate $\left(2-\mathrm{AQS}^{-}\right)$were used as acceptor molecules, and 1-pyrenesulfonate $\left(\mathrm{PyS}^{-}\right)$was used as a donor molecule in an aqueous solution of poly $(1,1-$ dimethyl-3,5-dimethylenepiperidinium chloride) $\left(\mathrm{PDDP}^{+} \mathrm{Cl}^{-}\right)$. The effects of the chemical structures of acceptor molecules on the strength of counterion binding and CT complexation were investigated, and molecular orbital calculation was used to explain the observed CT band difference between the $\mathrm{Na}^{+} \mathrm{PyS}^{-} / \mathrm{Na}^{+} 1-\mathrm{AQS}^{-} /$ $\mathrm{PDDP}^{+} \mathrm{Cl}^{-}$and $\mathrm{Na}^{+} \mathrm{PyS}^{-} / \mathrm{Na}^{+} 2-\mathrm{AQS}^{-} / \mathrm{PDDP}^{+} \mathrm{Cl}^{-}$ systems. Plausible models of the $\mathrm{CT}$ complexes are discussed on the basis of the calculations. 


\section{EXPERIMENTAL}

\section{Materials}

The solution of poly(1,1-dimethyl-3,5-dimethylenepiperidinium chloride) $\left(\mathrm{PDDP}^{+} \mathrm{Cl}^{-}\right)$used in the present work was purchased from Aldrich Chemical Co., Inc. as a $20 \mathrm{wt} \%$ aqueous solution. It was precipitated as described previously, and the powder of $\mathrm{PDDP}^{+} \mathrm{Cl}^{-}$was obtained. ${ }^{19}$ The weight-average molecular weight was determined by light scattering measurement to be $1.0 \times 10^{5}$ in $0.2 \mathrm{M} \mathrm{NaCl}$ solution and the degree of polymerization was $6.2 \times 10^{2}$.

Sodium 1-pyrenesulfonate $\left(\mathrm{Na}^{+} \mathrm{PyS}^{-}\right)$(Molecular Probes Inc.), sodium 9,10-anthraquinone-1-sulfonate $\left(\mathrm{Na}^{+} 1-\mathrm{AQS}^{-}\right)$(Kanto Chemical Co., Inc.), and sodium 9,10-anthraquinone-2-sulfonate $\left(\mathrm{Na}^{+} 2-\mathrm{AQS}^{-}\right)$(Tokyo Kasei Co., Ltd.) were of analytical grade and used without further purification. Chemical structures of $\mathrm{PDDP}^{+} \mathrm{Cl}^{-}, \mathrm{PyS}^{-}, 1-$ and 2-AQS ${ }^{-}$are shown in Chart 1.

Deionized distilled water was used as the solvent.

Concentrations were expressed in molar (repeating units) (M) for $\mathrm{PDDP}^{+} \mathrm{Cl}^{-}$and in molar (M) for the salts $\left(1 \mathrm{M}=1 \mathrm{~mol} \mathrm{dm}^{-3}\right)$.<smiles>CCC1CC(C)C[N+](C)(C)C1</smiles>

$\mathrm{PDDP}^{*} \mathrm{Cl}^{-}$<smiles>O=C1c2ccccc2C(=O)c2c([Ge])cccc21</smiles>

1-AQS-

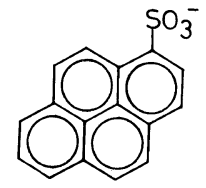

PyS-<smiles>O=C1c2ccccc2C(=O)c2cc([Se])ccc21</smiles>

2-AQS
Chart 1. The Chemical structures of $\mathrm{PDDP}^{+} \mathrm{Cl}^{-}, \mathrm{PyS}^{-}, 1-\mathrm{AQS}^{-}$ and $2-\mathrm{AQS}^{-}$.

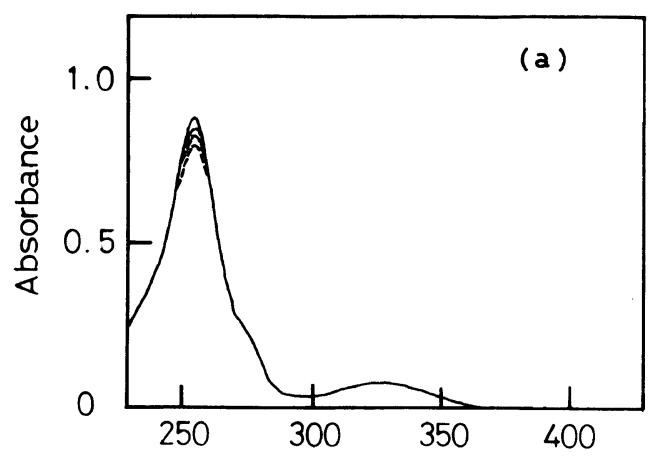

\section{Measurements}

Absorption spectra were recorded at $25^{\circ} \mathrm{C}$ on a Shimadzu 265FW spectrophotometer equipped with a thermostated cell. Quartz cells with light paths of $2 \mathrm{~mm}$ and $10 \mathrm{~mm}$ were used.

Steady-state fluorescence spectra of $\mathrm{Na}^{+} \mathrm{PyS}^{-}$were measured on a JASCO FP-777 fluorescence spectrometer at room temperature. The wavelength of the excitation was $365 \mathrm{~nm}$ to preferentially excite the molecule of $\mathrm{PyS}^{-}$.

Viscosity was measured with a modified Ubbelohde capillary viscometer at $25 \pm 0.01^{\circ} \mathrm{C}$. All polymer solutions were filtered through a JIS No. 3 sintered glass filter before measurements.

Solubility was measured as follows. Concentrated solutions of $\mathrm{Na}^{+} \mathrm{PyS}^{-}$and $\mathrm{Na}^{+} 1-\mathrm{AQS}^{-}$or $\mathrm{Na}^{+} 2-\mathrm{AQS}^{-}$ were added to that of the polymer in small vials, followed by adding appropriate amounts of water. The vials were shaken and set aside for 1 day. The presence of the precipitation of the polymer was examined visually. The tests were carried out at room temperature.

The rates of the binding of $\mathrm{Na}^{+} \mathrm{PyS}^{-}, \mathrm{Na}^{+} 1$-AQS and $\mathrm{Na}^{+} 2-\mathrm{AQS}^{-}$to the polyion were measured by ultrafiltration method. ${ }^{20}$ Counter ions with concentration of $1 \times 10^{-4} \mathrm{M}$ were added to the polymer solution of $\mathrm{PDDP}^{+} \mathrm{Cl}^{-}$at $3 \times 10^{-4} \mathrm{M}$, and then filtered by ultrafilter with cut off molecular weight $10^{4}$ dalton (CENTRICUT, Kurashiki Bouseki Co., Japan). The filtrates were measured by a spectroscopy meter to determine the concentrations of free counter ions.

Molecular orbital coefficients of $\mathrm{HOMO}^{-\mathrm{PyS}^{-}}$and LUMO of 1-AQS ${ }^{-}$and 2-AQS ${ }^{-}$were calculated using a semi-empirical molecular orbital method (MOPAC ${ }^{21}$ ver. 6.01 program using PM3 method ${ }^{22}$ ).

\section{RESULTS AND DISCUSSION}

Charge-Transfer Complexation between $\mathrm{PyS}^{-}$and 1-or 2- $A Q S^{-}$in an Aqueous Solution of $P D D P^{+} \mathrm{Cl}^{-}$

We first investigated self-association behavior of $\mathrm{PyS}^{-}$, $1-\mathrm{AQS}^{-}$, and $2-\mathrm{AQS}^{-}$in $\mathrm{PDDP}^{+}$solution. Figure 1 shows the absorption spectra of aqueous solutions of $\mathrm{Na}^{+} 1-\mathrm{AQS}^{-}$(a) and $\mathrm{Na}^{+} 2-\mathrm{AQS}^{-}$(b) in the presence and absence of $\mathrm{PDDP}^{+} \mathrm{Cl}^{-}$. In the presence of $\mathrm{PDDP}^{+} \mathrm{Cl}^{-}$, the absorption spectra of $\mathrm{Na}^{+} 2-\mathrm{AQS}^{-}$exhibit hypochromism with a significant red shift for the

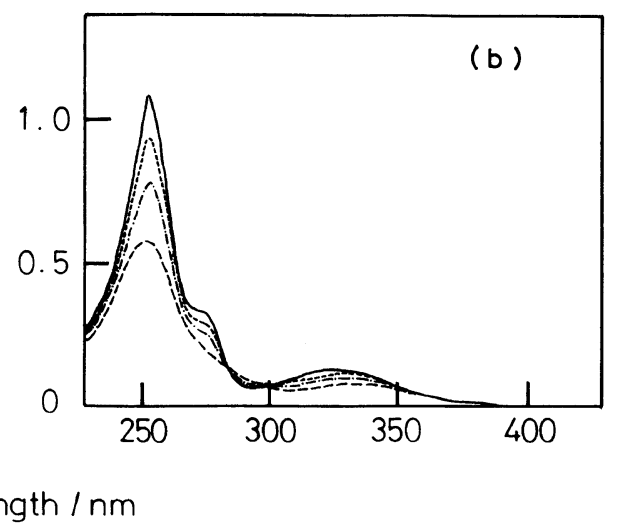

Figure 1. Absorption spectra of aqueous solutions of $\mathrm{Na}^{+} 1-\mathrm{AQS}^{-}$(a) and $\mathrm{Na}^{+} 2-\mathrm{AQS}^{-}$(b) in the presence and absence of $\mathrm{PDDP}^{+} \mathrm{Cl}^{-} . \mathrm{Cells}^{-}$ with a light path of $2 \mathrm{~mm}$ were used. $\left[\mathrm{Na}^{+} 1-\mathrm{AQS}^{-}\right]=1.10 \times 10^{-4} \mathrm{M} ;\left[\mathrm{Na}^{+} 2-\mathrm{AQS}^{-}\right]=1.10 \times 10^{-4} \mathrm{M} ;\left[\mathrm{PDDP}^{+} \mathrm{Cl}^{-}\right]=0 \mathrm{M}(\stackrel{\longrightarrow}{\longrightarrow}) ; 5.50 \times 10^{-5} \mathrm{M}$ $(--) 1.10 \times 10^{-4} \mathrm{M}(-\cdot-) ; 2.20 \times 10^{-4} \mathrm{M}(--)$. 
band near $330 \mathrm{~nm}$ and blue shift for the one near $250 \mathrm{~nm}$ as shown in Figure 1 (b). There are two isosbestic points in the $\mathrm{Na}^{+} 2-\mathrm{AQS}^{-} / \mathrm{PDDP}^{+} \mathrm{Cl}^{-}$systems. The presence of isosbestic points is an indication of association of $\mathrm{Na}^{+} 2-\mathrm{AQS}^{-}$molecules. The spectra of $\mathrm{Na}^{+} 1-\mathrm{AQS}^{-}$ showed little changes with the addition of $\mathrm{PDDP}^{+} \mathrm{Cl}^{-}$. This suggests that self-association does not occur between 1-AQS ${ }^{-}$molecules. The rates of binding of these molecules to $\mathrm{PDDP}^{+} \mathrm{Cl}^{-}$were determined by ultrafiltration. $^{20}$ The results showed that $98 \%$ of $\mathrm{PyS}^{-}, 70 \%$ of $1-\mathrm{AQS}^{-}$, and $96 \%$ of $2-\mathrm{AQS}^{-}$were bound to $\mathrm{PDDP}^{+} \mathrm{Cl}^{-}$. 1-AQS ${ }^{-}$thus has little tendency to make a self-association complex even though $70 \%$ was bound and concentrated in the vicinity of polyion moiety.

Figure 2 shows the absorption (a) and fluorescence (b) spectra of aqueous solution of $\mathrm{Na}^{+} \mathrm{PyS}^{-}$in the presence and absence of $\mathrm{PDDP}^{+} \mathrm{Cl}^{-}$. As the concentration of $\mathrm{PDDP}^{+} \mathrm{Cl}^{-}$increases, the absorption spectra exhibit hypochromism with significant red shifts and show several isosbestic points. This suggests that stacking interaction occurred in the vicinity of the polyion between $\mathrm{PyS}^{-}$molecules bound to $\mathrm{PDDP}^{+}$through counterion binding. The stacking interaction of $\mathrm{PyS}^{-}$'s in aqueous $\mathrm{PDDP}^{+} \mathrm{Cl}^{-}$solution is more clearly reflected in fluorescence spectra (Figure 2 (b)). In the absence of $\mathrm{PDDP}^{+} \mathrm{Cl}^{-}, \mathrm{PyS}^{-}$exhibited a characteristic spectrum of an isolated monomeric pyrene chromophore with peak positions at 380,400 , and $420 \mathrm{~nm}$. When $\mathrm{PDDP}^{+} \mathrm{Cl}^{-}$ was added to the $\mathrm{Na}^{+} \mathrm{PyS}^{-}$solution, the monomer emission intensity decreased and a broad excimer emission with a maximum near $500 \mathrm{~nm}$ appeared. Zimerman et al. ${ }^{23}$ observed the absorption and fluorescence spectra of $\mathrm{PyS}^{-}$in a solution of poly(vinyl benzyl trimethylammonium chloride). They concluded that there is polyion-induced ground state association of two or more $\mathrm{PyS}^{-}$'s. Our system showed similar association behavior of $\mathrm{PyS}^{-}$'s in $\mathrm{PDDP}^{+} \mathrm{Cl}^{-}$solution.

We next investigated the charge-transfer (CT) complexation between $\mathrm{PyS}^{-}$and 1- or $2-\mathrm{AQS}^{-}$in aqueous solution of $\mathrm{PDDP}^{+} \mathrm{Cl}^{-}$. In general, CT complexation between an electron-donor and an electron-acceptor is accompanied by color change. Control solutions of $\mathrm{Na}^{+} \mathrm{PyS}^{-} / \mathrm{PDDP}^{+} \mathrm{Cl}^{-}, \mathrm{Na}^{+} 1-\mathrm{AQS}^{-} / \mathrm{PDDP}^{+} \mathrm{Cl}^{-}$, and $\mathrm{Na}^{+} 2-\mathrm{AQS}^{-} / \mathrm{PDDP}^{+} \mathrm{Cl}^{-}$were all colorless. However, by the addition of $\mathrm{PDDP}^{+} \mathrm{Cl}^{-}$the color of the solution containing $\mathrm{Na}^{+} \mathrm{PyS}^{-}$and $\mathrm{Na}^{+} 1-$ or $2-\mathrm{AQS}^{-}$ changed to pale, or deep yellow, respectively.

Figure 3 shows the absorption spectra of the $\mathrm{Na}^{+} \mathrm{PyS}^{-} / \mathrm{Na}^{+} 1-\mathrm{AQS}^{-} / \mathrm{PDDP}^{+} \mathrm{Cl}^{-}$(a) and $\mathrm{Na}^{+} \mathrm{PyS}^{-} /$ $\mathrm{Na}^{+} 2-\mathrm{AQS}^{-} / \mathrm{PDDP}^{+} \mathrm{Cl}^{-}$(b) systems, respectively. In both systems, new broad absorption bands were observed. The wavelengths of absorption maxima of the new bands were obtained from the difference spectra obtained by subtracting the spectra of $\mathrm{Na}^{+} \mathrm{PyS}^{-} /$ $\mathrm{PDDP}^{+} \mathrm{Cl}^{-}$and $\mathrm{Na}^{+} \mathrm{AQS}^{-} / \mathrm{PDDP}^{+} \mathrm{Cl}^{-}$solutions from those of (a) and (b). To obtain accurate difference spectra, the rates of binding of the counter ions to the polyion and the association constants of the CT complexes should
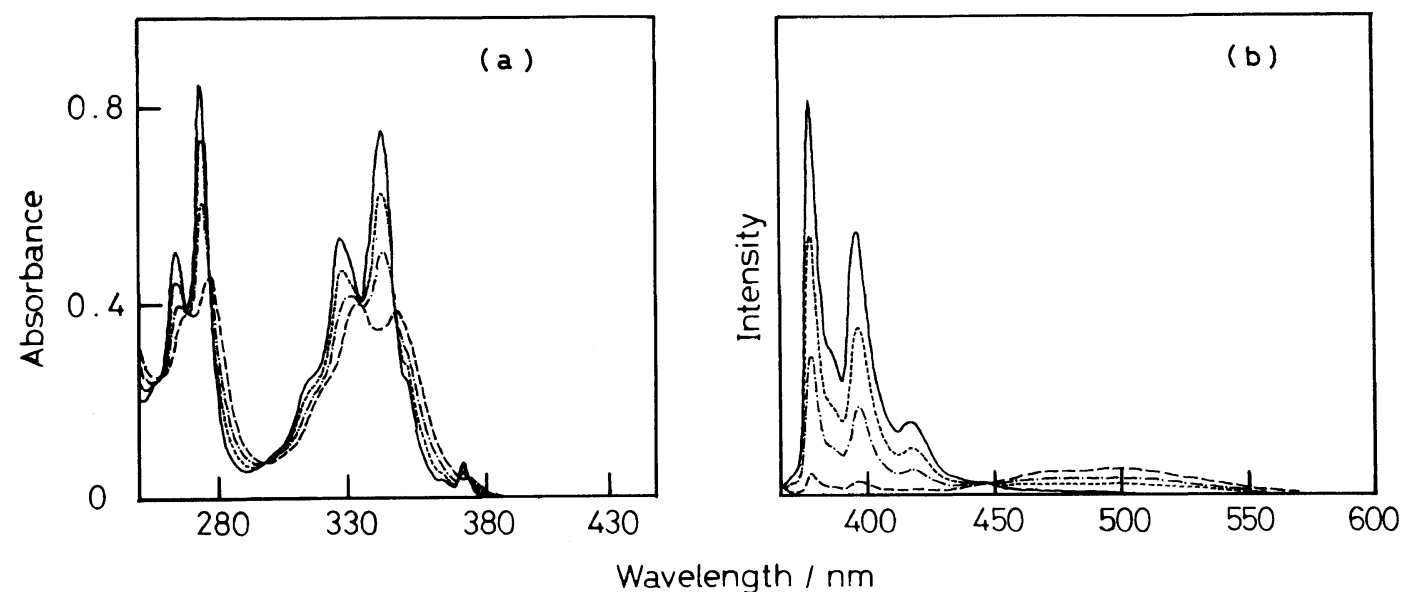

Figure 2. Absorption (a) and fluorescence spectra (b) of aqueous solutions of $\mathrm{Na}^{+} \mathrm{PyS}^{-}$in the presence and absence of $\mathrm{PDDP}^{+} \mathrm{Cl}^{-} . \mathrm{Cells}^{-1}$ with a light path of $2 \mathrm{~mm}$ were used. The fluorescence spectra were obtained by excitation at $365 \mathrm{~nm}$. $\left[\mathrm{Na}^{+} \mathrm{PyS}^{-}\right]=1.10 \times 10^{-4} \mathrm{M} ;\left[\mathrm{PDDP}^{+} \mathrm{Cl}^{-}\right]=0 \mathrm{M}$ $(-) ; 5.50 \times 10^{-5} \mathrm{M}(---) ; 1.10 \times 10^{-4} \mathrm{M}(-\cdot-) ; 2.20 \times 10^{-4} \mathrm{M}(--)$.
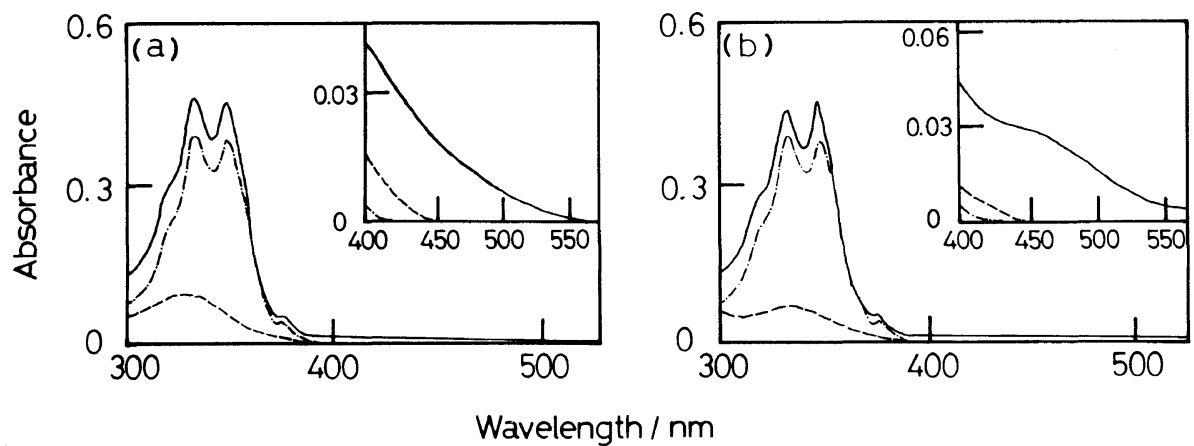

Figure 3. Absorption spectra of $\mathrm{Na}^{+} \mathrm{PyS}^{-} / \mathrm{Na}^{+} 1-\mathrm{AQS}^{-} / \mathrm{PDDP}^{+} \mathrm{Cl}^{-}$systems (a) and $\mathrm{Na}^{+} \mathrm{PyS}^{-} / \mathrm{Na}^{+} 2-\mathrm{AQS}^{-} / \mathrm{PDDP}^{+} \mathrm{Cl}^{-}$systems (b). $\mathrm{Na}^{+} \mathrm{PyS}^{-} / \mathrm{Na}^{+} \mathrm{AQS}^{-} / \mathrm{PDDP}^{+} \mathrm{Cl}^{-}(-) ; \mathrm{Na}^{+} \mathrm{PyS}^{-} / \mathrm{PDDP}^{+} \mathrm{Cl}^{-}(-\cdot-)$ and $\mathrm{Na}^{+} \mathrm{AQS}^{-} / \mathrm{PDDP}^{+} \mathrm{Cl}^{-}(---)$are also shown as controls. $\left[\mathrm{Na}^{+} \mathrm{PyS}^{-}\right]=1.10 \times 10^{-4} \mathrm{M} ;\left[\mathrm{Na}^{+} \mathrm{AQS}^{-}\right]=1.10 \times 10^{-4} \mathrm{M} ;\left[\mathrm{PDDP}^{+} \mathrm{Cl}^{-}\right]=4.40 \times 10^{-4} \mathrm{M}$. 
be considered. However, these constants are difficult to obtain in this system because the CT complex formed only when donor and acceptor molecules were closely bound to the polyion moiety. Exact association constants could not be obtained because the intensity of spectra was too low when counterion concentration was lowered. When counter ion concentration was raised, the polymer precipitated. So, the wavelength at the maxima obtained by the above-mentioned method should be considered as a first approximation. The wavelengths thus obtained are $c a .420 \mathrm{~nm}$ for the $\mathrm{Na}^{+} \mathrm{PyS}^{-} / \mathrm{Na}^{+} 1-\mathrm{AQS}^{-} / \mathrm{PDDP}^{+}$. $\mathrm{Cl}^{-}$system and $c a .450 \mathrm{~nm}$ for the $\mathrm{Na}^{+} \mathrm{PyS}^{-} / \mathrm{Na}^{+} 2-$ $\mathrm{AQS}^{-} / \mathrm{PDDP}^{+} \mathrm{Cl}^{-}$system. These new bands are ascribed to charge-transfer absorption bands (CT bands). Since these CT bands appear at low donor and acceptor concentrations of $\left[\mathrm{Na}^{+} \mathrm{PyS}^{-}\right]=\left[\mathrm{Na}^{+} 1-\mathrm{AQS}^{-}\right]=\left[\mathrm{Na}^{+} 2-\right.$ $\left.\mathrm{AQS}^{-}\right]=1.1 \times 10^{-4} \mathrm{M}, \mathrm{PyS}^{-}$and $1-$ or $2-\mathrm{AQS}^{-}$should be electrostatically concentrated in the vicinity of the polyion.

To determine the stoichiometry of the CT complexes formed in the presence of $\mathrm{PDDP}^{+}$, a continuous variation method (Job plot ${ }^{24}$ ) was used for the intensity of the CT band at the wavelength of $450 \mathrm{~nm}$ (Figure 4). The total concentration of the counter ions $\left(\left[\mathrm{Na}^{+} \mathrm{PyS}^{-}\right]+\left[\mathrm{Na}^{+} 1-\right.\right.$ $\left.\mathrm{AQS}^{-}\right]$or $\left.\left[\mathrm{Na}^{+} \mathrm{PyS}^{-}\right]+\left[\mathrm{Na}^{+} 2-\mathrm{AQS}^{-}\right]\right)$and concentration of $\mathrm{PDDP}^{+} \mathrm{Cl}^{-}$were adjusted to $2.20 \times 10^{-4} \mathrm{M}$ and $4.40 \times 10^{-4} \mathrm{M}$, respectively, for all points measured. In both systems, a maximum appeared at $X=0.5$, where $X=\left[\mathrm{Na}^{+} \mathrm{PyS}^{-}\right] /\left(\left[\mathrm{Na}^{+} \mathrm{PyS}^{-}\right]+\left[\mathrm{Na}^{+} 1-\right.\right.$ and $\left.\left.2-\mathrm{AQS}^{-}\right]\right)$. By taking into account that most $\mathrm{PyS}^{-}$and 2-AQS ${ }^{-}$ counter ions binded to the moiety of polyion, it can be said that $1: 1$ type CT complex formed between $\mathrm{PyS}^{-}$ and $2-\mathrm{AQS}^{-}$in the system. In the case of $1-\mathrm{AQS}^{-}$, only $70 \%$ of counter ions binded to the polyion. In this case, this method gives not quantitative but qualitative results. If we estimate the donor-acceptor ratio of this CT complex at the maximum point of $X=0.5$ by taking into account the rate of binding of $1-\mathrm{AQS}^{-}$to the polyion, it leads to $1: 0.7 \mathrm{CT}$ complex. This suggests that $1: 1$ type CT complexes were formed, because the number of molecules in the complex should be an integer.

To study the effects of an added salt on the CT complexation in both $\mathrm{Na}^{+} \mathrm{PyS}^{-} / \mathrm{Na}^{+} 1-\mathrm{AQS}^{-} / \mathrm{PDDP}^{+}$$\mathrm{Cl}^{-}$and $\mathrm{Na}^{+} \mathrm{PyS}^{-} / \mathrm{Na}^{+} 2-\mathrm{AQS}^{-} / \mathrm{PDDP}^{+} \mathrm{Cl}^{-}$systems,

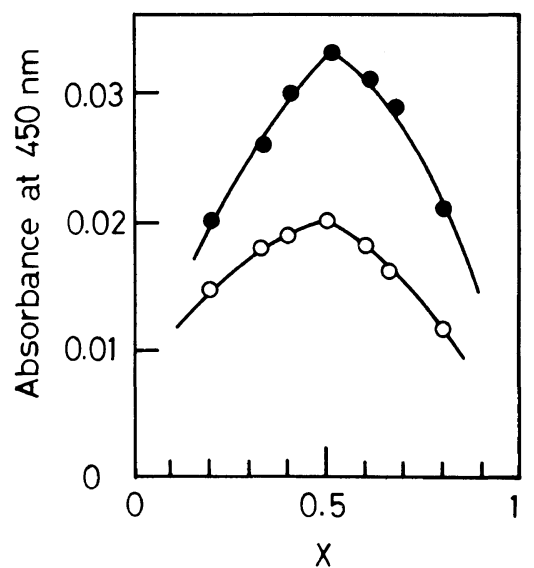

Figure 4. Continuous variation plots for CT complexation between $\mathrm{PyS}^{-}$and $1-\mathrm{AQS}^{-}(\mathrm{O})$ and $2-\mathrm{AQS}^{-}(\mathrm{O})$ in aqueous solution of $4.40 \times 10^{-4} \mathrm{M} \quad \mathrm{PDDP}^{+} \mathrm{Cl}^{-} . \quad X=\left[\mathrm{Na}^{+} \mathrm{PyS}^{-}\right] /\left(\left[\mathrm{Na}^{+} \mathrm{PyS}^{-}\right]+\left[\mathrm{Na}^{+}-\right.\right.$ $\left.\left.\mathrm{AQS}^{-}\right]\right),\left[\mathrm{Na}^{+} \mathrm{PyS}^{-}\right]+\left[\mathrm{Na}^{+} \mathrm{AQS}^{-}\right]=2.20 \times 10^{-4} \mathrm{M}$.
$\mathrm{NaCl}$ was added to these solutions as the second added salt. The absorbance of the CT band at $450 \mathrm{~nm}$ was monitored and plotted against $\mathrm{NaCl}$ concentration (Figure 5). In the $\mathrm{Na}^{+} \mathrm{PyS}^{-} / \mathrm{Na}^{+} 1-\mathrm{AQS}^{-} / \mathrm{PDDP}^{+} \mathrm{Cl}^{-}$ system, the addition of $\mathrm{NaCl}$ caused gradual decrease in the intensity of the CT band, which suggests the destruction of the CT complex between $\mathrm{PyS}^{-}$and $1-\mathrm{AQS}^{-}$due to counter ion exchange between the CT complex and $\mathrm{Cl}^{-}$in the polyion moiety. In the $\mathrm{Na}^{+} \mathrm{PyS}^{-} /$ $\mathrm{Na}^{+} 2-\mathrm{AQS}^{-} / \mathrm{PDDP}^{+} \mathrm{Cl}^{-}$system, the $\mathrm{CT}$ band is unchanged by the addition of $\mathrm{NaCl}$ up to $[\mathrm{NaCl}]=c a$. $1 \times 10^{-2} \mathrm{M}$. However, further addition of $\mathrm{NaCl}$ leads to an abrupt decrease in the intensity of the CT band. These results indicate that the CT complex between $\mathrm{PyS}^{-}$and $2-\mathrm{AQS}^{-}$is more resistant to destruction than that between $\mathrm{PyS}^{-}$and $1-\mathrm{AQS}^{-}$in the vicinity of the polyion. The precise cause for the difference in the stability of 1- or 2-AQS ${ }^{-} \mathrm{CT}$ complex system could not be elucidated in this work, but the importance of the position of $-\mathrm{SO}_{3}{ }^{-}$ group on the counterion binding to the polyion and on the CT complexation is clearly indicated. In the stabilization, hydrophobic interactions may also play important roles as well as the electrostatic and chargetransfer interactions.

Viscosity and Solubility Behaviors of $\mathrm{PDDP}^{+} \mathrm{Cl}^{-}$in Aqueous $\mathrm{Na}^{+} \mathrm{PyS}^{-} / \mathrm{Na}^{+}$- - or $2-\mathrm{AQS}^{-}$solutions

The physico-chemical properties of aqueous polyelectrolyte solution depend on the concentration and/or the type of added salts. ${ }^{25}$ Especially in the present system, since CT complexation occurs between counterions in the vicinity of the polyion, viscosity and solubility behavior of $\mathrm{PDDP}^{+} \mathrm{Cl}^{-}$should also be affected by the structure of the CT complexes and/or interactions between the polyion and CT complexes.

Figure 6 shows the reduced viscosity of $\mathrm{PDDP}^{+} \mathrm{Cl}^{-}$ $\left(4.11 \times 10^{-4} \mathrm{~g} \mathrm{ml}^{-1}\right)$ in solutions of $\mathrm{Na}^{+} \mathrm{PyS}^{-} / \mathrm{Na}^{+} 1$ $\mathrm{AQS}^{-}(1: 1), \mathrm{Na}^{+} \mathrm{PyS}^{-} / \mathrm{Na}^{+} 2-\mathrm{AQS}^{-}(1: 1), \mathrm{NaCl}$, and $\mathrm{Na}_{2} \mathrm{SO}_{4}$ as a function of their concentrations $\left(C_{\mathrm{s}}\right)$. In all systems, the reduced viscosities, $\eta_{\mathrm{sp}} / c$, decrease with increasing added salt concentration. The reduced viscosities of the $\mathrm{PDDP}^{+} \mathrm{Cl}^{-}$solution decrease with the addition of $\mathrm{Na}^{+} \mathrm{PyS}^{-} / \mathrm{Na}^{+} 1-\mathrm{AQS}^{-}$and $\mathrm{Na}^{+} \mathrm{PyS}^{-}$ $\mathrm{Na}^{+} 2-\mathrm{AQS}^{-}$more than with the addition of the same moles of $\mathrm{NaCl}$. The magnitudes of the decrease in the viscosity of the former solutions are rather close to the one with divalent anion, $\mathrm{SO}_{4}{ }^{2-}$. The previous paper ${ }^{14}$

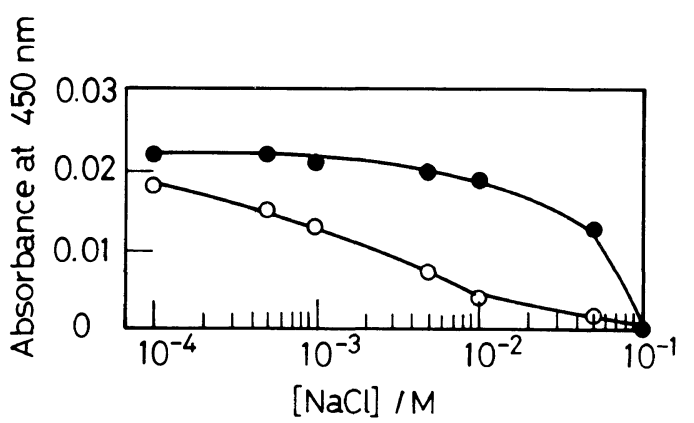

Figure 5. Effects of added salt $(\mathrm{NaCl})$ on absorbance at $450 \mathrm{~nm}(\mathrm{CT}$ band) of $\mathrm{Na}^{+} \mathrm{PyS}^{-} / \mathrm{Na}^{+} 1-\mathrm{AQS}^{-} / \mathrm{PDDP}^{+} \mathrm{Cl}^{-}$(O) and $\mathrm{Na}^{+} \mathrm{PyS}^{-} /$ $\mathrm{Na}^{+} 2-\mathrm{AQS}^{-} / \mathrm{PDDP}^{+} \mathrm{Cl}^{-}$(O) systems. $\left[\mathrm{Na}^{+} \mathrm{PyS}^{-}\right]=1.10 \times 10^{-4} \mathrm{M}$; $\left[\mathrm{Na}^{+} 1-\mathrm{AQS}^{-}\right]=1.10 \times 10^{-4} \mathrm{M} ; \quad\left[\mathrm{Na}^{+} 2-\mathrm{AQS}^{-}\right]=1.10 \times 10^{-4} \mathrm{M}$; $\left[\mathrm{PDDP}^{+} \mathrm{Cl}^{-}\right]=4.40 \times 10^{-4} \mathrm{M}$. 
pointed out that the monovalent aromatic counter ions are similar to divalent anions in association behavior around poly(allylammonium) cation. In this study, $1: 1$ types of CT complexes were preferentially formed around $\mathrm{PDDP}^{+}$. The present CT complexes may also be considered to behave as divalent anions. These CT complexes that have similar character to divalent anion shield the charged groups on $\mathrm{PDDP}^{+}$more effectively than simple $\mathrm{Cl}^{-}$, and as a consequence, the polymer chain becomes more compact, and its reduced viscosity decreases. The decrease in the reduced viscosity of the polymer is more prominent in the $\mathrm{Na}^{+} \mathrm{PyS}^{-} / \mathrm{Na}^{+} 2$ $\mathrm{AQS}^{-}$system than $\mathrm{Na}^{+} \mathrm{PyS}^{-} / \mathrm{Na}^{+} 1-\mathrm{AQS}^{-}$system. This suggests that in the $\mathrm{Na}^{+} \mathrm{PyS}^{-} / \mathrm{Na}^{+} 2-\mathrm{AQS}^{-}$system the charges of $\mathrm{PDDP}^{+}$are shielded more effectively than in the $\mathrm{Na}^{+} \mathrm{PyS}^{-} / \mathrm{Na}^{+} 1-\mathrm{AQS}^{-}$system. The difference in the hydrophobicity between $1-$ and $2-\mathrm{AQS}^{-}$may also be connected with the difference, that is, hydrophobicity of the complexes may also be an important factor of decrease in the viscosity of $\mathrm{PDDP}^{+} \mathrm{Cl}^{-}$, because decrease in the viscosity of $\mathrm{Na}^{+} \mathrm{PyS}^{-} / \mathrm{Na}^{+} 2-\mathrm{AQS}^{-}$system is more

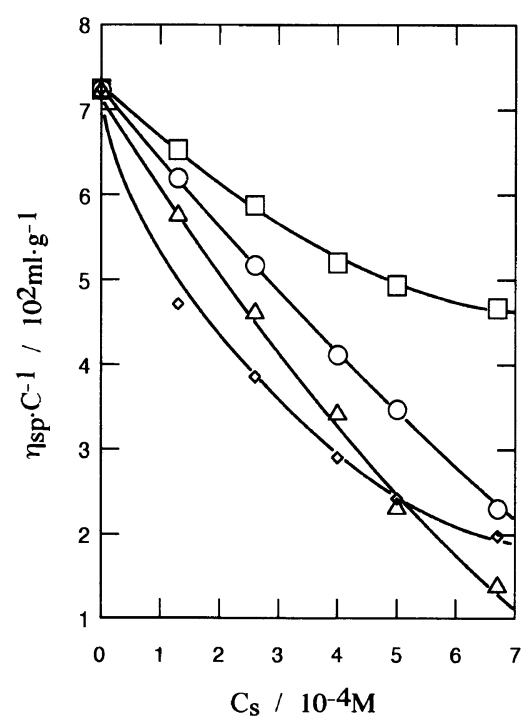

Figure 6. Reduced viscosities of $\mathrm{PDDP}^{+} \mathrm{Cl}^{-}\left(4.11 \times 10^{-4} \mathrm{~g} \mathrm{ml}^{-1}\right)$ in $\mathrm{NaCl}(\square), \mathrm{Na}^{+} \mathrm{PyS}^{-} / \mathrm{Na}^{+} 1-\mathrm{AQS}^{-}(\mathrm{O}), \mathrm{Na}^{+} \mathrm{PyS}^{-} / \mathrm{Na}^{+} 2-\mathrm{AQS}^{-}(\triangle)$, and $\mathrm{Na}_{2} \mathrm{SO}_{4}(\diamond)$ solutions at $25^{\circ} \mathrm{C}$. $\mathrm{Na}^{+} \mathrm{PyS}^{-} / \mathrm{Na}^{+} \mathrm{AQS}^{-}(1: 1)$. than that of simple divalent anion, $\mathrm{SO}_{4}{ }^{2-}$, when the counter ion concentration is higher than $5 \times 10^{-4} \mathrm{M}$.

A similar difference can be seen in the solubility diagrams of $\mathrm{PDDP}^{+} \mathrm{Cl}^{-}$in the $1: 1 \mathrm{Na}^{+} \mathrm{PyS}^{-} / \mathrm{Na}^{+} 1-$ $\mathrm{AQS}^{-}$and $1: 1 \mathrm{Na}^{+} \mathrm{PyS}^{-} / \mathrm{Na}^{+} 2-\mathrm{AQS}^{-}$systems (Figure 7). The dashed line represents an equimolar ratio of $\mathrm{PDDP}^{+} \mathrm{Cl}^{-}$(monomer unit) to total concentration of the added salts $\left(C_{\mathrm{s}}=\left[\mathrm{Na}^{+} \mathrm{PyS}^{-}\right]+\left[\mathrm{Na}^{+} 1-\right.\right.$ or $2-$ $\left.\mathrm{AQS}^{-}\right]$). A precipitation region (hatched) of the $\mathrm{Na}^{+} \mathrm{PyS}^{-} / \mathrm{Na}^{+} 2-\mathrm{AQS}^{-}$system extends to lower salt and higher polymer concentration region than $\mathrm{Na}^{+} \mathrm{PyS}^{-} /-$ $\mathrm{Na}^{+} 1-\mathrm{AQS}^{-}$system. The precipitation behavior of polyelectrolytes by addition of a salt can be interpreted in terms of the counterion binding and/or the ion pair formation. ${ }^{26}$ Generally, to precipitate a polyion, much of added salt is needed to shield sufficiently the charges of a polyion by salts. However, in the present $\mathrm{Na}^{+} \mathrm{PyS}^{-} / \mathrm{Na}^{+} 1$-and $2-\mathrm{AQS}^{-} / \mathrm{PDDP}^{+} \mathrm{Cl}^{-}$systems, it should be noted that the polymer precipitated even when the molar ratio of $\mathrm{PDDP}^{+} \mathrm{Cl}^{-}$(monomer unit) to total concentration of $\mathrm{Na}^{+} \mathrm{PyS}^{-}$and $\mathrm{Na}^{+} 1-$ and $2-\mathrm{AQS}^{-}$is larger than unity $\left(C_{\mathrm{p}}>C_{\mathrm{s}}\right)$. That is, the precipitation of $\mathrm{PDDP}^{+} \mathrm{Cl}^{-}$does not require excess salt. CT complexation thus leads to effective charge shielding and/or ion pair formation. This gives additional proof that the CT complex behaves like a divalent anion rather than monovalent counter ion. Hydrophobic interaction should also be considered important in this case.

\section{Structure of CT Complexes between $\mathrm{PyS}^{-}$and 1-and $2-A Q S^{-}$in the Vicinity of $P D D P^{+}$}

$C T$ interaction generally occurs through partial electron transfer from the highest occupied molecular orbital (HOMO) of donor molecule to lowest unoccupied molecular orbital (LUMO) of acceptor molecule. ${ }^{27,28}$ These energy levels are usually perturbed by chargetransfer interactions which lower the energy level of HOMO and raises that of LUMO, respectively, the extent depending on the magnitude of $\mathrm{CT}$ interaction. This makes it difficult to compare the excitation energy between different molecules using a semi-empirical molecular orbital calculation. However, in the present systems, $\mathrm{PyS}^{-}$is a common donor in both systems, and
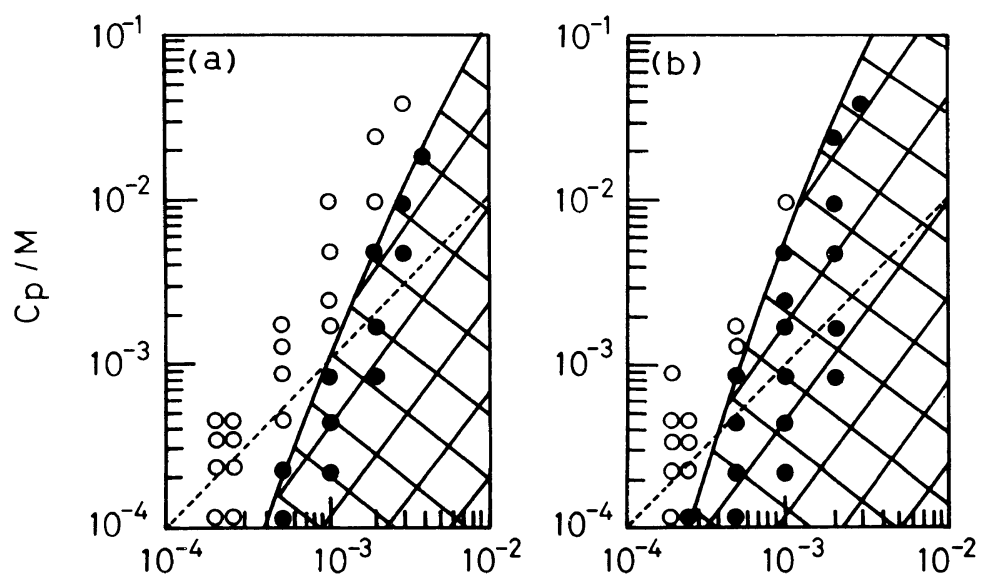

Cs / M

Figure 7. Solubility diagrams of $\mathrm{PDDP}^{+} \mathrm{Cl}^{-}$in aqueous $\mathrm{Na}^{+} \mathrm{PyS}^{-} / \mathrm{Na}^{+} 1-\mathrm{AQS}^{-}$(a) and $\mathrm{Na}^{+} \mathrm{PyS}^{-} / \mathrm{Na}^{+} 2-\mathrm{AQS}^{-}$(b) solutions. Symbols indicate turbid solution $(O)$ or precipitation $(O)$ of the polymer. $C_{\mathrm{p}}$ and $C_{\mathrm{s}}$ represent concentration of the polymer in residue molar concentration $(M)$ and molar concentrations of the aromatic salts $\left(\left[\mathrm{Na}^{+} \mathrm{PyS}^{-}\right]:\left[\mathrm{Na}^{+} 1-\mathrm{AQS}^{-}\right]=\left[\mathrm{Na}^{+} \mathrm{PyS}^{-}\right]:\left[\mathrm{Na}^{+} 2-\mathrm{AQS}^{-}\right]=1: 1\right), \mathrm{respectively}$. 
acceptor molecules of 1 - and $2-\mathrm{AQS}^{-}$have only small difference in their molecular structures. This means that change in the LUMO levels by CT interactions should also be nearly the same in 1- and 2-AQS ${ }^{-}$molecules. Therefore, it is reasonable to consider that the relative difference between the excitation energies for these two systems can well be approximated by the energy difference in the energy level of LUMO between 1- and 2-AQS ${ }^{-}$molecules. Molecular orbital calculations (MOPAC $^{21}$ version 6.01 program using PM3 method $^{22}$ ) showed that the LUMO energy level in $1-\mathrm{AQS}^{-}$is higher than that in $2-\mathrm{AQS}^{-}$by $0.158 \mathrm{eV}$. This energy difference corresponds to $24 \mathrm{~nm}$ in wavelength from the maximum wavelength of $450 \mathrm{~nm}$. This is consistent with the observed values. That is, the CT band for $1-\mathrm{AQS}^{-}$system appears at shorter wavelength by $c a .30 \mathrm{~nm}$ than that for 2-AQS ${ }^{-}$system.

Finally, we tried to elucidate plausible structures of the CT complexes by considering the overlap of orbitals between HOMO of $\mathrm{PyS}^{-}$and LUMO of $1-\mathrm{AQS}^{-}$or

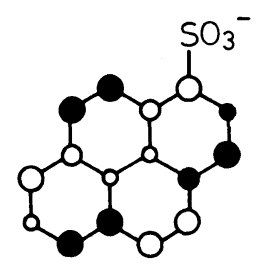

HOMO of PyS

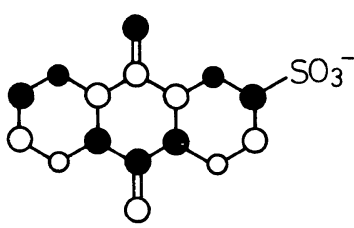

LUMO of $2-\mathrm{AQS}^{-}$

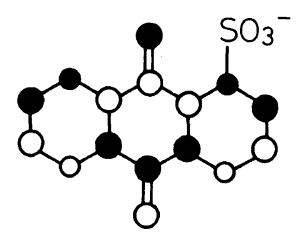

LUMO of $1-A Q S^{-}$
Figure 8. Molecular orbital coefficients of $\mathrm{HOMO}$ of $\mathrm{PyS}^{-}$and $\mathrm{LUMO}^{-} \mathrm{AQS}^{-}$and $2-\mathrm{AQS}^{-}$.

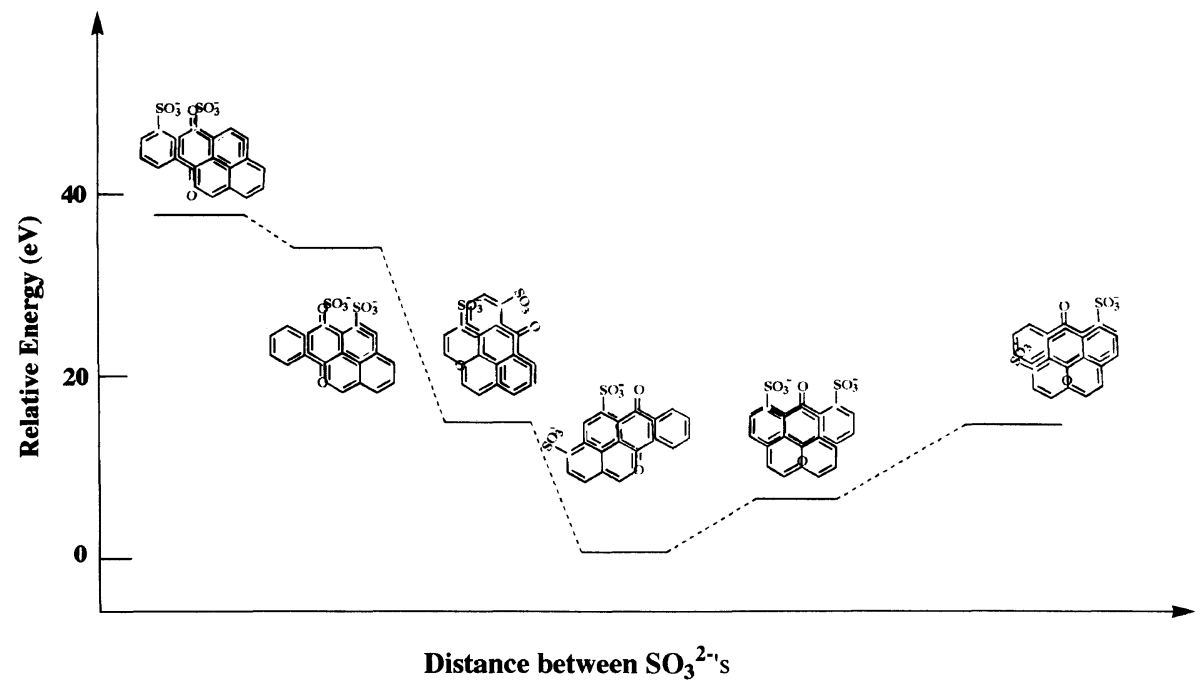

Figure 9. Comparison of total energies of plausible structures for the $\mathrm{CT}$ complexes between $\mathrm{PyS}^{-}$and $1-\mathrm{AQS}^{-}$at various orientations. Relative energy for each CT complex is shown in the order of distances between $-\mathrm{SO}_{3}{ }^{-}$'s.

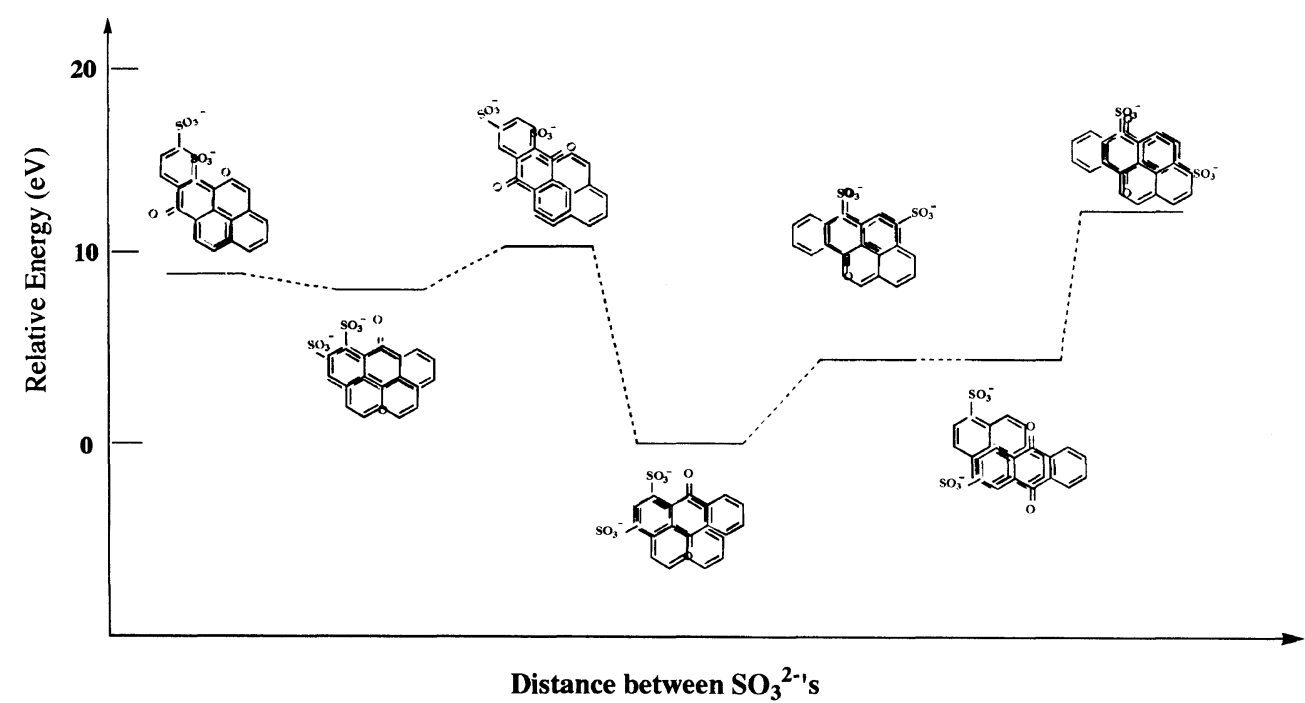

Figure 10. Comparison of total energies of plausible structures for the CT complexes between $\mathrm{PyS}^{-}$and 2-AQS ${ }^{-}$in various orientations. Relative energy for each CT complex is shown in the order of distances between $-\mathrm{SO}_{3}^{-}$'s. 

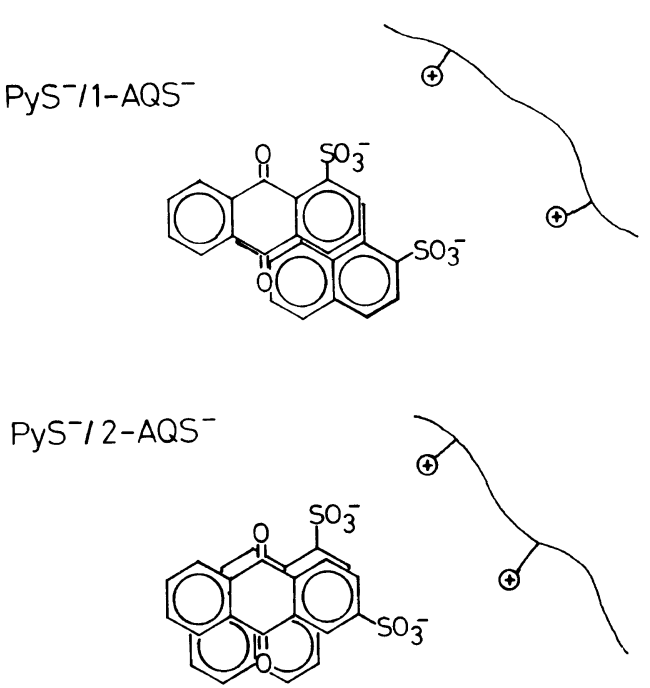

Figure 11. Plausible structures of the CT complexes around the polycation.

2-AQS ${ }^{-}$. Figure 8 illustrates the molecular orbital coefficients of HOMO for PyS ${ }^{-}$and those of LUMO for 1- and 2-AQS ${ }^{-}$. To infer plausible structures of CT complexes, we consider the following conditions. First, orbital overlapping between HOMO of donor and LUMO of acceptor should be maximized in the CT complex structures. Secondly, interactions between $\mathrm{PDDP}^{+}$and the counter ions $\left(\mathrm{PyS}^{-}, 1-\right.$ or $2-\mathrm{AQS}^{-}$) are mostly electrostatic. This forces the $-\mathrm{SO}_{3}{ }^{-}$groups of donor and acceptor molecules to bind to cationic sites of the polymer. By these electrostatic interactions, the distance between the $-\mathrm{SO}_{3}{ }^{-}$groups should be small. However, there is an electrostatic repulsion between $\mathrm{PyS}^{-}$and $\mathrm{AQS}^{-}$because of the same charge $\left(-\mathrm{SO}_{3}{ }^{-}\right)$. Therefore, the orientation of the charged groups of donor and acceptor molecules should be determined by the balance between the above attractive and repulsive forces. In the calculation, $\mathrm{NH}_{4}{ }^{+}$ions were used as contact ion pairs of $-\mathrm{SO}_{3}{ }^{-}$residues instead of the polyion. Taking into account the above conditions, we selected some plausible structures as candidates for CT complexes, i.e., which have large overlap of molecular orbitals and smaller distances between the $-\mathrm{SO}_{3}{ }^{-}$residues. The single point molecular orbital calculations were performed for these candidates and relative energies are shown in Figures 9 and 10. Intermolecular plane-to-plane distances between $\mathrm{PyS}^{-}$and $\mathrm{AQS}^{-}$were kept at $3.3 \AA^{29}$ in all calculations. The lowest energy structures were selected and interaction models with $\mathrm{PDDP}^{+}$are shown in Figure 11. When $\mathrm{PyS}^{-}$and 1- or 2-AQS ${ }^{-}$overlap each other as shown here, the symmetry-allowed interaction between HOMO of the donor and LUMO of the acceptor is attained.

\section{REFERENCES}

1. F. Oosawa, "Polyelectrolytes," Marcel Dekker Inc., New York, N.Y., 1971.

2. H. Eisenberg and G. R. Mohan, J. Chem. Phys., 63, 671 (1959).

3. C. J. Leyte, H. L. Zuiderweg, and J. H. Vledder, Spectrochim. Acta, 23A, 1397 (1967).

4. H. Morawetz and B. Vogel, J. Am. Chem. Soc., 91, 563 (1969).

5. I. A. Taha and H. Morawetz, J. Am. Chem. Soc., 93, 829 (1971).

6. I. Satake, M. Fukuda, T. Ohta, K. Nakamura, F. Fujita, A. Yamauchi, and H. Kimizuka, J. Polym. Sci., Polym. Phys. Ed., 10, 2343 (1972).

7. S. Miyamoto, Macromolecules, 14, 1054 (1981).

8. J. Mattal and J. C. T. Kwak, J. Phys. Chem., 86, 1026 (1982).

9. A. E. Lewis, J. T. Barkley, R. R. Reams, D. L. Hansen, and T. St Pierre, Macromolecules, 17, 2874 (1984).

10. T. Kitano, S. Kawaguchi, K. Ito, and A. Minakata, Macromolecules, 20, 1598 (1987).

11. B. Boussouira, A. Ricard, and R. Audebert, J. Polym. Sci., Part $B, 26,649$ (1988).

12. M. Satoh, E. Yoda, and J. Komiyama, Macromolecules, 24, 1123 (1991).

13. H. E. Rios, G. A. Ternero, R. G. Barraza, and I. C. Gamboa, J. Polym. Sci., Polym. Phys. Ed., 32, 215 (1994).

14. T. Itaya, K. Ueda, and H. Ochiai, Polym. J., 24, 539 (1992).

15. T. Itaya, K. Ueda, H. Ochiai, and A. Imamura, Polym. J., 25, 545 (1993).

16. T. Itaya, H. Ochiai, K. Ueda, and A. Imamura, Macromolecules, 26, 6021 (1993).

17. R. W. Gilkerson and L. A. Mixon, J. Solution Chem., 19, 491 (1990).

18. T. Itaya, Y. Kawabata, H. Ochiai, K. Ueda, and A. Imamura, Bull. Chem. Soc. Jpn., 67, 1538 (1994).

19. T. Itaya, Y. Kawabata, H. Ochiai, K. Ueda, and A. Imamura, Bull. Chem. Soc. Jpn., 67, 2047 (1994).

20. Y. Kawabata, T. Itaya, Y. Sasaki, H. Ochiai, K. Ueda, and A. Imamura, Polym. J., 27, 542 (1995).

21. J. J. P. Stewart, MOPAC Ver. 5.0: QCPE \#455; Frank J. Seiler Research Laboratory, U.S. Air Force Academy, Colorado Springs, Colorado 80840-6528, U.S.A.

22. J. J. P. Stewart, J. Comput. Chem., 10, 221 (1989).

23. O. E. Zimerman, J. J. Cosa, and C. M. Previtali, J. Macromol. Sci., Pure Appl. Chem., A31, 859 (1994).

24. D. Job, Ann. Chem. Phys., 10, 113 (1928).

25. P. H. Gregor and M. Frederick, J. Polym. Sci., 23, 451 (1957).

26. A. Ikegami and N. Imai, J. Polym. Sci., 56, 133 (1962).

27. R. S. Mulliken, J. Am. Chem. Soc., 74, 811 (1952).

28. R. S. Mulliken, Rec. Trav. Chim. Pays-Bas., 75, 845 (1956).

29. C. K. Prout and B. Mayah, J. Chem. Soc., Faraday Trans. 2, 68, 1072 (1972) 